\title{
CALDERON COKEMAKING \\ PROCESS/DEMONSTRATION PROJECT
}

Quarterly Technical Report

Reporting Period Start Date: 11/26/1998 End Date: 02/25/1999

Author: ALBERT CALDERON

Report Issue Date: 03/19/1999

DE-FC22-95PC92638--15

CALDERON ENERGY COMPANY

500 Lehman Avenue

P.O. Box 126

Bowling Green, OH 43402 


\section{DISCLAIMER}

This report was prepared as an account of work sponsored by an agency of the United States Government. Neither the United States Government nor any agency thereof, nor any of their employees, makes any warranty, express or implied, or assumes any legal liability or responsibility for the accuracy, completeness, or usefulness of any information, apparatus, product, or process disclosed, or represents that its use would not infringe privately owned rights. Reference herein to any specific commercial product, process, or service by trade name, trademark, manufacturer, or otherwise does not necessarily constitute or imply its endorsement, recommendation, or favoring by the United States Government or any agency thereof. The views and opinions of authors expressed

herein do not necessarily state or reflect those of the United States Government or any agency thereof. 


\section{QUARTERLY TECHNICAL PROGRESS REPORT \\ CALDERON COKEMAKING PROCESS/DEMONSTRATION PROJECT \\ CALDERON ENERGY COMPANY \\ COOPERATIVE AGREEMENT NO. DE-FC22-95PC92638}

Reporting Period: 11-26-98 to 2-25-99

Date of Report: 3-19-99; Award Date: 5-25-95; Anticipated Completion Date: 11-25-99

Total Project: $\$ 7,354,195.00 \quad$ Total DOE Share: $\$ 3,039,389.00$

Contracting Officer's Representative (COR): Dr. Michael J. Baird;

Project Director: Albert Calderon

$\underline{\text { Abstract }}$

This project deals with the demonstration of a coking process using proprietary technology of Calderon, with the following objectives geared to facilitate commercialization:

(i) making coke of such quality as to be suitable for use in hard-driving, large blast furnaces;

(ii) providing proof that such process is continuous and environmentally closed to prevent emissions;

(iii) demonstrating that high-coking-pressure (non-traditional) coal blends which cannot be safely charged into conventional by-product coke ovens can be used in the Calderon process; and

(iv) demonstrating that coke can be produced economically, at a level competitive with coke imports. 
The activities of the past quarter were focused on the following:

- $\quad$ Consolidation of the team of stakeholders;

- $\quad$ Move the site for the commercial demonstration to LTV Steel, Cleveland, Ohio;

- $\quad$ Permitting for new site;

- $\quad$ Site specific engineering;

- Cost update of the project as it relates to the Cleveland location;

- $\quad$ FETC update;

- $\quad$ DCAA audit;

- $\quad$ Updated endorsement of Calderon process by Ohio EPA and U.S. EPA, Region 5; 


\section{TABLE OF CONTENTS}

Introduction

Page 1

Accomplishments and Discussion

Page 1

Conclusion

Page 4 


\section{Introduction}

The commercialization path of the Calderon cokemaking process consists of the following general phases:

Phase I-- Proof of capability to produce acceptable product coke, proof of the process being environmentally closed, proof that non-conventional coal blends can be used, and proof that coke can be economically produced domestically using U.S. metallurgical coals at a level competitive with low cost-producer coke produced from foreign countries that are not subjected to U.S. environmental standards.

Phase II-- Scale-up of coking reactor to full commercial size (PDU-II) in support of first commercial facility.

Phase III-- Construction and operation of first commercial facility.

Phase IV-- Worldwide commercialization of the technology to produce coke competitive with that produced by low-cost producer coke-exporting countries.

\section{Accomplishments and Discussion}

During the past quarter the work was focused in the following areas: team consolidation, new site, permitting for the new site, engineering which is site specific, an updated cost estimate, and other activities relating to the administration of the project.

\section{$\underline{\text { Team Consolidation }}$}

The possible team members for this project as previously reported were Bethlehem Steel, Bechtel, Koppers, Alliance Machine and Vesuvius. 
Bethlehem Steel, which received approval to invest $\$ 5$ million of which $\$ 3.3$ million is cash and \$1.7 million in-kind (consisting of coal and technical services) remains unaltered. The president of Bechtel's Mining and Metals Division did take the request for a $\$ 5$ million investment (consisting of $\$ 1.25$ million in cash and $\$ 3.75$ million in services) to the Chairman's Leadership Council (CLC) of Bechtel; the request was approved. The vice president for technology at Koppers made a request for \$5 million (50\% in cash and 50\% in-kind) to the management of Koppers; the request was denied by reason that business conditions have deteriorated and the company was short of resources. The president of Alliance Machine Company agreed to request \$5 million (50\% cash and 50\% in services) from the owners of Alliance; because of strategic reasons such request was going to be presented on March 15, 1999. Vesuvius' president made a request for an investment from the parent company of $\$ 2.5$ million (\$1.0 million in cash and \$1.5 million in-kind in the form of special tiles required for the coking reactor); this request was denied but the parent company agreed to furnish the tiles at cost and no cash.

Since the goal is to have the private sector committed to $\$ 20$ million, and the only commitments in place were essentially Bethlehem and Bechtel for $\$ 5$ million each, it was decided to approach LTV again with the request that LTV agrees to the following: (1) site the demonstration facility at its previous \#1 coke plant in Cleveland; and (2) supply the coal and consume 80,000 tons of coke from the demonstration facility in support of a blast furnace. The value of such contribution is $\$ 9.6$ million based on coke costs of $\$ 120 /$ ton which is the current production costs of coke at LTV. A letter from Mr. Hipple, Executive Vice President is attached to this report, which indicates that LTV is prepared to consider Calderon's request. 
Based on the contributions from Bethlehem, Bechtel, LTV and Vesuvius, the 50\% (\$20 million) from the private sector is therefore do-able, and letters of commitment to this effect are forthcoming from these stakeholders.

\section{$\underline{\text { New Site }}$}

In view of LTV's agreement to locate the cokemaking facility (full-size commercial demonstration) on its property in Cleveland, permitting work was begun. A permit is currently in place for locating the facility in Alliance and this permit needs to be re-applied for the Cleveland site. Engineering as it relates to this specific site has also begun. The previous \#1 coke plant offers many advantages when compared to the Alliance site, such as using the battery pad to serve as a foundation base for the reactor and also the use of the foundation of the 1800 tons coal bunker (which will be demolished) to serve as the base for the hot gas cleanup. Other advantages include access to utilities, and ample room for parking and equipment lay-down.

\section{$\underline{\text { Cost Update }}$}

In locating the facility in Alliance, certain equipment that is in place was going to be used but a whole new foundation with piling and reinforcement of the existing structural steel was an added cost. In the Cleveland site, the civil and concrete work will be minimal and substantial savings would occur by virtue of the access to utilities and especially to large transformers, steam as well as the low cost for electric power which will be made available by LTV. Therefore a cost update was conducted as it relates to locating the demonstration facility in Cleveland.

\section{$\underline{\text { FETC Update }}$}

On the $12^{\text {th }}$ of February, 1999, a meeting was held at FETC (Pittsburgh) to update DOE of the progress made regarding the Calderon technology. This meeting was attended by Bethlehem 
Steel, Bechtel, Calderon and a large group of DOE representatives. Both Bethlehem and Bechtel represented to DOE that each would be contributing $\$ 5$ million to the project. Subsequent to the update it was concluded that Calderon's team will apply to Congress for the Government's portion (\$20 million) to assist in the construction and in the two (2) year operation of the full-size commercial demonstration of the Calderon's technology for cokemaking.

\title{
DCAA Audit
}

During this quarter, an audit which lasted several days was conducted by DCAA at the offices of Calderon Energy. The manner in which the funds were being used was acceptable and traceable. No changes were required.

\section{EPA Update}

Both the U.S. EPA and the Ohio EPA issued letters regarding the Calderon process for making coke based on actual observation. Such letters which are positive in nature, are attached.

\section{Conclusion}

Much progress was made during the reported quarter. Letters of financial and resources commitment from all stakeholders are expected to be in place during the next quarter. With such commitments in place, it is intended to approach Congress for the U.S. Government's portion. In the meantime engineering will continue with the Cleveland site conditions being taken into account. Other formal documents with the stakeholders are expected to be executed during the coming quarter.

Submitted by:

\author{
Albert Calderon \\ Project Director
}




\section{LTV LTV Steel Company, Inc.}

EXECUTIVE VICE PRESIDENT

February 22, 1999

Mr. Albert Calderon

Calderon Energy Co. of Bowling Green

P. O. Box 126

Bowling Green, $\mathrm{OH} 43402$

Dear Albert:

LTV has considered your idea to locate a cokemaking facility at LTV's property in Cleveland, along with LTV supplying coal and consuming coke from the facility to support a blast furnace test.

LTV would like the opportunity to support your exciting approach to new cokemaking technology.

Please let me know how we might best proceed to work out a mutually acceptable agreement surrounding your ideas.

Sincerely,

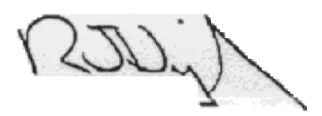

Richard J. Hipple

Executive Vice President

$\mathrm{RJH} / \mathrm{sec}$

EXECUTIVE VICE PRESIDENT • LTV STEEL COMPANY, INC. 200 PUBLIC SQUARE, \#14-419 • CLEVELAND, OHIO 44114-2308

TELEPHONE (216) 622-4900 • FAX (216) 622-1062 


\section{OPA}

State of Ohio Environmental Protection Agency

Northeast District Office

2110 E. Aurora Road

Twinsburg, Ohio 44087-1969

(330) 425-9171

George V. Voinovich

FAX (330) 487-0769

Governor

December 9, 1998

Mr. Albert Calderon

Calderon Energy Co. of Bowling Green

P.O. Box 126

Bowling Green $\mathrm{OH} 43402$

Dear Mr. Calderon:

During the fall of 1997, your Process Demonstration Unit in Alliance, Ohio did a trial operation producing coke from coal using the equipment permitted by Ohio EPA under Permit to Install No. 02-11099. This equipment had been modified, the original equipment installed under Ohio EPA Permit No. 02-3860, as equipment for coal conversion technology.

I visited the facility on November 3,1997 and observed the plant in operation. Coke was being produced using the sealed, pressurized reactor with charges every 24 minutes. The only vent on the process was through the flare, no emissions of any type were observed during, charging, pushing or operation.

I have worked on all the air quality permits for this facility and have been impressed to see that it has operated as cleanly as the company has claimed it would.

During the November 3, 1997 demonstration, Dana Thompson of the Ohio EPA's Central Office was also in attendance representing Robert Hodanbosi, the Ohio EPA, Division of Air Pollution Control Director who had been invited.

Please contact me if any other demonstration operations are planned for the Alliance plant. If I can be of any assistance, please feel free to contact me at (330) 963-1243.

Sincerely,

$$
\text { Robent Moulish }
$$

Robert Goulish, P.E.

Environmental Engineer

Division of Air Pollution Control

RG:ddb 


\section{UNITED STATES ENVIRONMENTAL PROTECTION AGENCY \\ REGION 5 \\ 77 WEST JACKSON BOULEVARD \\ CHICAGO, IL 60604-3590}

PEPLY TO THE ATTENTION OF

March 5, 1999

B-19J

Michael J. Baird, Ph.D

Project Manager

U.S. Department of Energy

Federal Energy Technology Center

P.O. Box 10940, MS 922247A

Pittsburgh, PA 15236-0940

Mike:

The purpose of this letter is to formally transmit to you my February 11, 1999, E-mail message regarding the recent meeting on the Calderon Energy coke making technology. Again, I apologize that I could not attend the meeting. Although I had intended for my message to be included as part of the meeting, I understand that you did not receive it until after the meeting was completed. I hope that it will nonetheless be helpful to you.

Feel free to contact me if $I$ can be of further assistance in this matter.

Sincerely,

Eof loj jacetwe $\leqslant$.

Ed Wojciechowski

Regional Iron and Steel Liaison

Enclosure

cc: Albert Calderon

Calderon Energy 
February 11, 1999

\section{VIA E-MAIL}

Mike Baird, Engineer

Department of Energy

Fuel Resources Division

Process Energy Technology Center

Bruceton, PA

Mike:

This note is in lieu of my attendance at the Department of Energy (DOE) meeting on February 12, 1999, regarding funding of further development of the Calderon Energy coke making technology. I apologize for not being able to attend the meeting on behalf of the United States Environmental Protection Agency (US EPA).

The US EPA has been concerned with the potential harmful effects of air emissions from coke making facilities since the 70 's. In an effort to reduce hazardous benzene emissions from these facilities, US EPA promulgated standards under the National Emission Standards for Hazardous Air Pollutants (NESHAP) in September 1989, regulating emissions from the by-product recovery operations of coke making facilities. In October 1993, to further reduce these emissions, standards were promulgated for the coke batteries themselves. US EPA is currently evaluating the need for yet additional NESHAP regulations covering emissions from coke pushing and quenching operations, and from the underfire stack.

Water pollution from coke making facilities has also been problematic. Historically, coke making has generated wastewater that contains ammonia, cyanide, phenol and benzene. US EPA is also concerned about tar decanter sludge, a listed hazardous waste, which is generated in the by-product recovery area.

Based upon my first-hand knowledge of over two dozen coke plants during my last twenty-two years with US EPA, industry has made great strides in reducing coke plant emissions. However, the very nature of producing coke with conventional slot type coke ovens continues to present environmental concerns. Their operation is maintenance-intensive, requiring constant surveillance on the part of the company, in order to maintain compliance with environmental regulations while continuing viable economic operation.

I am personally familiar with the coke making technology under development by Calderon Energy, having first learned about it in 1994 from its inventor, Albert Calderon. In late 1994, Calderon Energy gave a presentation about the technology at US EPA's Region 5 office in Chicago, Illinois. I was impressed with what I had learned, and it was clear to me that there was also interest on the part of the steelmaking industry, as evidenced by the presence of a representative of LTV Steel.

In October 1997, I visited the Calderon Energy facility in Alliance, Ohio, to see first-hand the operation of the company's pilot oven. While details of the trip are memorialized in a US EPA, 
Region 5 memorandum dated February 4, 1998, I will add here that the technology clearly has the potential for multimedia benefits. It is a net user of water, minimizing problems in this area. There is no by-product recovery plant, which significantly reduces hazardous air emissions and the generation of tar decanter sludge. Additionally, there was no visible smoke or dust at any time during the trip, nor were there any noticeable odors.

Of major importance to US EPA currently is the generation of emissions that contribute to global warming. In a letter to Albert Calderon of Calderon Energy dated April 21, 1998, from Jack Edwardson, Associate Director, Emission Standards Division, Office of Air Quality Planning and Standards, US EPA acknowledged that this technology shows great promise for reducing greenhouse gases.

Overall, there are numerous potential environmental benefits to the Calderon Technology that I recommend DOE consider in evaluating this project for continued federal funding. 